\title{
THE ARTISTIC EMBODIMENT OF THE IMAGE OF ENGLAND IN THE «LETTERS TO ANOTHER ROOM» BY RAVIL BUKHARAYEV
}

\author{
Alina R. Gaynutdinova ${ }^{1}$ \\ Alfiya F. Galimullina ${ }^{2}$ \\ Foat G. Galimullin ${ }^{3}$ \\ Abay K. Kairzhanov ${ }^{4}$
}

\begin{abstract}
The problem of the writer's self-identification, especially of such a multifaceted one as Ravil Bukharayev, is closely connected with one of the topical problems of modern literary criticism and cultural studies - the problem of the Other. Ravil Raisovich Bukharayev
\end{abstract} (1951 - 2012) - a Tatar poet, writer, philosopher who wrote in Russian, lived for more than 20 years in England. In his work he demonstrates a new cultural situation, the ability to seamlessly apprehend the universal art culture, literature and worldview ideas from ancient times to the present day at the same time preserving his national and religious identity. The poetry by $\mathrm{R}$. R. Bukharayev has repeatedly become the object of scientific research while the philosophical prose by R. R. Bukharayev is still waiting for his researcher. This article represents the experience of a scientific study of the artistic world of RR Bukharayev's prose based on the example of his novel Letters to Another Room [1]. The results of our study suggest the following conclusions: The novel by R. R. Bukharayev "Letters to Another Room" presents the perception of England through the Other's vision of it. R. R. Bukharayev representing himself as the Other in relation to the English tradition upends the preconceived idea of the English "gentleman" as the only bearer of the English literary and cultural tradition. Irony and self-irony help the narrator to isolate himself from Englishness of the

\footnotetext{
${ }^{1}$ Kazan Federal University

${ }^{2}$ Kazan Federal University. alfiya_gali1000@mail.ru. 79053100964.

${ }^{3}$ Kazan Federal University

${ }^{4}$ Gumilyov Eurasian National University
} 
created text: 1)The image of England in the novel by R. R. Bukharayev is ambiguous: on the one hand, the narrator found a real House with a wonderful garden, a place of rest and creativity in it, on the other - the author is far from idealizing English society. He seeks maximum objectivity in the artistic presentation of the image of England in his novel. 2)A distinctive feature of R. R. Bukharayev's narrative is an integration of Russian and English realities in the text, which is manifested in comparisons of English everyday realities with memories of Russian life. In the minds of the author the images and associations connected with English and Russian literature and culture organically coexist.

Keywords: Ravil Bukharaev, Russianlanguage literature, the Other in literature and culture, the image of England in literature, artistic reception

\section{Introduction}

Ravil Bukharayev is a multicultural poet, writer, publicist, philosopher who synthesizes many cultures in his work: Russian, Tatar, English. R.R. Bukharayev traveled extensively around the world. $\mathrm{He}$ is a scholar, his prose and poetry are suffused with many associations. He carries on a dialogue that goes into a polylogue with the reader, with his beloved woman, with his friends and fellow-thinkers, with modern and ancient writers, poets, composers, musicians, philosophers and thinkers of all time.

All of the above can be attributed to Letters to Another Room. The Mirror of Silence by R.R. Bukharayev, written in March - August 2001 and included in The Book of Confessions of the five-volume collected works by R. Bukharayev [1]. These letters are dedicated to his wife and friend, the muse of the poet-philosopher - the poetess Lydia Grigoriyeva. The novel is in the form of a mental monologue addressed to Her, in which throughout the narrative the similarities and differences between the authornarrator and his companion in the perception of literature, culture, the world in general, and England in particular are clearly traced. Here we observe, on the one hand, the binary opposition of the women's and men's views of the world, and on the other hand, the search for the ways to overcome it in mutual understanding. In 
the narrative R.R. Bukharaev's characters, while retaining recognizable biographical features, are simultaneously typified, turning into the subjects of dialogue - polylogue that $\mathrm{He}$ and She hold.

In the first chapter of the novel

Letters to Another Room, R. Bukharayev, foreseeing a comparison of himself with the long-held belief of English "gentleman" as a bearer of the English literary and cultural tradition, clearly indicates his position of the Other with respect to the Englishness of the text he creates. Irony and self-irony come to the narrator's aid: "В Англии наконеи происходит весна: так ли нечто должно всегда происходить и свершаться в душе?”, -меланхолично записал бы я золотым паркеровским пером на белоснежной манжете, будь я в то раздумчивое мгновение марта безупречно одетым вечерним джентльменом хоть бы $и$ из старинного лондонского клуба “Атениум” - словом, если б я был человеческим существованием из тех, что ритуально препровождают положенное время в глубоких зеленокожаных креслах, в них же пьют принесенный белофрачным
201

официантом, но отвратительно заваренный, желтоватый $и$ еле тепльй грушевый чай $\quad$ и промежутках между беседами листают газеты" " [1: p. 13] (Spring has finally come in England: should something always happen in the soul?", I would write in a melancholic way with a golden Parker pen on a snow-white cuff if in that thoughtful moment of March I were an impeccably dressed evening gentleman even from an old London club "Athenium"- In a word if I were a human being of those who ritually spend the appointed time in capacious green-skinned chairs, in them they also drink disgustingly brewing, yellowish and slightly warm pear tea brought by a white-haired waiter, looking through newspapers in the intervals between conversations).

The narrator carefully shrugs off English aristocracy, emphasizing his otherness, primarily ethnic: “... $a$ галстучными бабочками и теми единственными золотыми запонками, на которых печатка с татарским гербом, щэеголяю крайне редко..." [1: p. 13]. (and I make an extremely rare parade of a bow-tie and 
the only gold collar buttons on which a signet with the Tatar coat of arms)

Thus, by listing the external attributes of an English gentleman: a Parker pen, snow-white cuffs, bow-ties, membership in the old London club Atenium, deep green-skinned armchairs, pear tea and reading newspapers - the narrator contrasts them with one thing that is external - a signet with the Tatar coat of arms, which indicates his Tatar origin.

\section{Methods}

Comparative literary criticism traditionally considers the problem of inter-literary reception. The works by A.N. Veselovsky, M.P. Alekseyev, V.M. Zhirmunsky, I.G. Neupokoyeva, D. Dyurishin study the basic theoretical principles of Russian comparative literature [2-4]. The application of the comparative method to the literary correlation of Russian literature with English literature in our investigation involves the identification of genetically contact literary relations such as direct and indirect, external and internal, influences and borrowings.

When studying the specifics of manifestation of the Other category in modern literature and culture (of the ethnocultural, the existential) and the features of the artistic presentation of the image of England in Russian literature, we mainly focused on the works by modern scholars: E.N. Shapinskaya, L.F. Khabibullina, T.N. Breyeva, V.R. Amineva, V.N. Krylov, Z.R. Zinnatullina, R.F. Bekmetov, E.F. Nagumanova, A. M. Sayapovo, V.B. Shamina [5 - 14].

Thus, the methodological basis of our study was comparative historical, comparative functional, thematic, mythological and comparative typological methods that allowed us to identify the specifics of the artistic presentation of the image of England in the novel of the modern Russianspeaking Tatar writer - R. R. Bukharayev.

\section{Results and discussion}

Letters to Another Room. The Mirror of Silence by R. Bukharayev comprehends the category "Other" in the very title of the work, that is, it is placed in a strong position of the text. In the course of the analysis we determined that in the novel Letters to Another Room R. Bukharayev enters into a dialogue with 
the representatives of English literature in order to more clearly explain his original stand in life. Thus, in the first chapter there is a quote from Oscar Wilde into the narrator's reflections on the essence of a true English gentleman: “Хватает пока и скоротечной памяти, в которой среди прочего засел и филигранный экспромт некогда главного здесь законодателя мод и мьсллей, ирладияа Оскара Уайльда: «все мы сидим в канаве, но некоторые из нас при этом глядят в небеса" " [1: p. 14] (There will be a fleeting memory enough, in which, among other things, the filigree impromptu of formerly main setter of trends and thoughts, Irishman Oscar Wilde, has stuck: "we are all sitting in a ditch, but some of us are looking to the skies). Then R. Bukharayev, sweeping away the mask of a gentleman that readers and researchers could ascribe to him summarizes, "It is also believed that in order not simply to look like, namely, to be a first-rate gentleman, one must be born in a three-piece suit with a bow-tie and to settle in a suit from an early age, otherwise another masquerade will turn out: for all the worldly need for this, completely alien masks misfit my face and slide off easily, especially since the most difficult thing, as it turned out, is to be who you are and not fear the consequences." [1: p.14].

The text of R.R. Bukharayev's novel is distinguished by intertextuality, an abundance of quotes, author's digressions and inset stories. Standing upon his right to an original judgment, which is different from that generally accepted in English society, the narrator argues that the most difficult task of an individual is to maintain his integrity.

R. Bukharayev's novel begins with a description of the morning in the country house of two Poets, two personalities in keeping with the spirit of traditional English novels: a fortress house, an English house surrounded by a beautiful garden, harmony between Man and Nature reigns in everything. The storyteller enjoys contemplating nature.

The idea of the House and its surrounding garden in R. Bukharayev's narrative is gradually given among various discussions about path of life, about honesty, about the imaginary and the real, about the process of cognition and attainment of Truth. In the description by R.R. Bukharayev House appears in the best traditions of Victorian 
novels: “Сам дом, на пороге которого расточались минуты молчания, наш каменный дом на вершине холма, окруженный с севера всходящим по склону истомившимся в озябших почках действенным лесом, а с югазавитым вездесущиим плющуом кирпичным забором и маленьким, созданным твоими трудами садом в наричиссах, крокусах и гиациинтах ...” [1: p. 26] The very house, on the threshold of which minutes of silence were dissipated, our stone house on the top of the hill, surrounded from the north by powerful forest, languishing in the quenched buds, descending along the slope, and from the south by a brick fence enwrapped in the omnipresent ivy and a small garden full of daffodils, crocus and hyacinths created with your efforts....

The architecture of the house emphasizes the self-sustainability of the worlds of two creative personalities living in it: “две рабочие комнаты, два нетождественных мира, где в надобности могут укрыться полезное чтение и письменный труд, сопряжены для нас единой стеною ...” [1: p. 27] two work rooms, two nonidentical worlds, where useful reading and writing can take shelter, are connected for us with a single wall .... The architecture of the house also corresponds to the inner spiritual attitude of its inhabitants. He is a Muslim, she is an Orthodox Christian, he is an early riser, she is a late riser, but it is not in the way of their love and understanding, the unity of their thoughts. There are many such comparisons and contrasts of the two main characters on the pages of the novel: “Так же многоразличны порой и наши верованья и стремленья, и все ж тем яснее проницают пространство крова и мира обоюдные связи, сцепляя существованья в обоих мирах, и все различья и разнииь здесь пребывают в единстве, а благодати взаимных безмолвий порой проницают осязаемую реальность, как острие молодого листка пронициает древесную почку, а слеза проницает житейскую косность лиияа" [1: p. 27] (Our beliefs and aspirations are also sometimes different, and reciprocal ties permeate through the space of shelter and peace more clearly, linking existence in both worlds, and all the differentiations and differences here are in unity, and the graces of mutual silence 
sometimes penetrate tangible reality like a sharp point a new leaf penetrates the tree bud, and a tear penetrates the everyday inertia of the face)

\section{Summary}

In Letters to Another Room by R. Bukharayev an important marker of Englishness in the literary text formed in English literature of the 19th century emerges full blown. As noted by L.F. Khabibullina, "a bourgeois rural or urban house is the space of the family, or social space, the house in this variety is present in the whole realistic novel of the 19th century" [15: p. 283]. At the same time, according to a modern Russian scholar: "Such a house is a sphere of realization of the idea of the English as an orderly nation, adhering to a strict hierarchy and strict morals. This type of house is found in an English realistic novel from Jane Austen's to John Galsworthy's ...” [15: p. 283].

So, the description of the House with a garden fits into the English literary tradition. The narration by R.R. Bukharayev is a mental journey that dates back to the 18th-century English philosophical novels; it is not by chance that Lorentz Stern's Sentimental Journey
205

through England and France, is several times mentioned, which has marked the beginning of the European noveljourney.

The rejection of the official business life of London is reflected in the composition of the novel: the first chapter describes in detail every minute of the storyteller performing morning prayer, enjoying the contemplation of an awakening garden and strong coffee, dressed "in a winter Tashkent green quilted robe without pockets and buttons", reflecting on the vicissitudes of life and outlining creative plans [1: $\mathrm{p}$. 26]. The last eighth chapter of $R$. Bukharayev's novel Crying ends with the part entitled Postscript. It contains not only the events of daily workdays but the events of summer and early autumn. Everyday vanity in the Russian BBC department is succinctly characterized: «Вот и не знаю, возвращаюсь я восвояси или ухожу прочь, поднимаясь каждый вечер сквозь закатный Далический лес на вершину Сиденамского холма после смены на Бибиси, проведенной в неистовой гонке за последними новостями планеты. Ведь и вправду всякий день в мире случаются громкие, - и чем 
страшнее, тем громче, - вещи и происшествия, и весь радио-мир по расписаниям сеток вещанья как о чемто единственно важном

говорит,

говорит,

говорит,

говорит,

говорит,

говорит

о вещах, о которых назавтра

уже никто и не вспомнит, кроме тех людей, с кем они на беду приключились» [1: p. 273]. I don't know whether I'm going back home or going away, rising every evening through the sunset Dalichsky forest to the top of Sydenamsky hill after the shift to $\mathrm{BBC}$, held in a frantic race for the latest news on the planet. Indeed, every day in the world publicized things happen - and the worse, the more famous things and incidents are, and the whole radio world according to the schedules of broadcasting networks as something unique speaks, speaks, speaks, speaks, speaks, speaks about the things that tomorrow no one will remember, except for those people with whom they had unfortunately happened
A six-fold repetition of the word "speaks", reinforced by means of a graphic accentuation similar to the famous "ladder" of V. Mayakovsky expressively demonstrates the attitude of the narrator to his work, emphasizing its routine and futility.

On the contrary, the events that took place during the summer - autumn in the garden surrounding the fortress house are more significant for the author, therefore they are described circumstantially: "Пока, прерываемое большими (Bukharayev's italics - A.G.) событиями мира, о которых исправно вещал я невидимым людям, как бы и сами собою писались эти долгие письма, незаметно свершилась весна, и вот оказалось, что уже завершается август. Между тем и в нашем саду, который и нынче застану я уже в загустевающей тьме, были за лето собственные происшествия" [1: p. 273] (So far, interrupted by large events of the world, about which I properly broadcast to invisible people, as if these long letters were being obviously written, the spring came, and it turned out that August is already ending. Meanwhile, in our garden, which I still find now in thickening darkness, there 
happened my own incidents over the summer).

Among the events significant for the storyteller are the flowering of the jasmine bush, the behavior of the squirrels that lived on the garden maple, the hunt of the beloved cat of the inhabitants of the house - Mumzika, "who once found a huge and absolutely living common stag-beetle in the crevice of an old stump. I saved a beetle from the cat ..." [1: p. 274]. В неспешном повествовании важна каждая деталь и даже жизнь случайно спасенного жука приобретает смысл, поэтому целый абзац посвящается его описанию In a deliberate narrative, every detail is important and even the life of a randomly saved beetle makes sense, so the whole paragraph deals with its description: «Сей жучище, Licanus cervus, рогач в подвижно сочлененном панцире, с лапками в сильных зубцах, хищными оружейными челюстями и сложными своими глазами...» This bug, Licanus cervus, a stag in a movably articulated carapace, with paws in strong teeth, predatory arms jaws and complex eyes ... [1: p. 274]. In fact, the description of the beetle is a poem in prose, the evidence of importance of each living creature for the universe and worthy of our attention on a level with reflections on Being and the latest news.

Descriptions of the garden crown the author's thoughts on the Unity of all that exist. In R. Bukharayev's narrative, reflections on complex philosophical categories are interspersed with everyday details and etymological information: thus, the description of the August garden smoothly proceeds to forecasts for early autumn, which has different names for different peoples: Russians call it "Old Wives' Summer", "it is "Indian" in English. This name came from America (...), and earlier, before the dominance from across the pond, Indian summer was called here (in England - noted by A. G.) "St. Luke's summer" or "St. Martin's summer", or even All Saints Summer, All-Hallown summer [1: p. 275]. In confirmation of his words, R. Bukharayev quotes from Shakespeare, thereby again referring to the English literary source, thereby returning the story to a high philosophical stream: ““"Farewell, thou latter spring; farewell, All-Hallown summer!" -William Shakespeare exclaimed in an exalted syllable saying 
goodbye to the spring and Old Wives' Summer, who, perhaps, was not there, nor will we, but will there be at least one line from us in the coming silence?" [1: p. 275].

\section{Conclusions}

Concluding the results of our investigation, we note that R.R. Bukharayev, having lived in England for about 20 years, did not feel like an emigrant, he often came to Kazan, successfully integrated into Tatar public life. Via his verses and poems, proses and dramatic works, he artistically comprehended the pressing issues of the present in the context of the historical past of the Tatars, Russia and in the global historical and literary context.

At the same time, in R.R. Bukharayev's work we observe the tendencies inherent in modern literary and cultural process: in his work, there prevail synthesis, harmonious unity and adoption of Western, specifically English and generally English literature and culture along with traditional binary oppositions such as "East / West", "Christian / Muslim". He was open to new knowledge, he was omniscient, therefore, throughout the pages of his works of literature, regardless of a genre variation, well-known philosophers, writers, composers of all times and peoples often enter into dialogue. This tendency in modern culture is indicated by E.N. Shapinskaya [5 - 6].

We accept M.I. Ibragimov's viewpoint that "one can talk about multiple identities in relation to $R$. Bukharaev's work. Images of world culture and literature, numerous allusions and reminiscences form the space of his poetry as a space of dialogue. Bukharaev's personage is included in many topoi, he is a man of the world, prehensive to different cultures and languages" [16: p.85-86].

As is well known, the problem of the writer's self-identification, especially of such a multifaceted one as Ravil Bukharayev, is closely connected with the problem of the Other. As noted by E.N. Shapinskaya, "in cultural texts ... there is an appropriation of the Other, which can also be of a double nature: enduing it with "own" qualities and recognizing "friendliness" without accompanying hostility" [5: p. 52]. In the case of R.R. Bukharayev, in our opinion, the latter is observed. 


\section{Acknowledgements}

The work is performed according to the Russian Government Program of Competitive Growth of Kazan Federal University.

\section{Bibliography}

Bukharayev R.R. Letters to Another Room, a Mirror of Silence. // Bukharayev R.R. Selected Works: The Book of Confessions / RR Bukharaev. Kazan: Magarif - Vakyt, 2011. - P. 13 280.

Alekseyev M.P. Pushkin and World Literature. - L.: Nauka, 1987. - 616 p.

Neupokoyeva I. G. History of World Literature. Problems of Systemic and Comparative Analysis. - M.: Nauka, 1976. - 359 p.

Dyurishin D. Theory of Comparative Study of Literature. - M.: Progress, 1979. - $320 \mathrm{p}$.

Shapinskaya E.N. The Image of the Other in Cultural Texts: Poetics of Representation // Humanitarian Knowledge: Theory and Methodology. 2009. - Issue 3. - P. 51 - 56.
Shapinskaya E.N. Selected Works on the Philosophy of Culture. - M.: Soglasiye, 2014. - 456 p.

Zinnatullina Z.R, Khabibullina L.F. Analyzing the «internal other» in English literature: Welsh characters in J. Fowles «A Maggot» and A. Burgess «Any Old Iron»//Rupkatha Journal on Interdisciplinary Studies in Humanities. - 2018. - Vol.10, Is.2. - P. 87-94.

Amineva V.R. Dialogue with Another as a Form of Self-Identification of the Lyrical Subject of N. Gambar / V.R. Amineva // Przegląd wschodniosłowiański. 2018. IX/1. - pp. 331-342.

Krylov V. I deas about national identity in russian literary review, historical and literary discourses of the 19th-early 20th century//CBU international conference proceedings 2017: Innovations in science and education. - 2017. - Vol.5, Is.. - P.680-685.

Sibgatullina V. Krylov V., Govoruhina,Y. Polemical aspects of the travelogue genre theory // National academy of managerial staff of culture 
and arts herald .2018. - Issue 2. pp.276-279

Bekmetov R.F., Ozerova K.A. Pushkin and China // Ad Alta: Journal of Interdisciplinary Research. - 2018. Vol. 10. Issue 1. - Special III. - Pp. 1517.

Bekmetov R.F., Gazizov R.R., Spirchagova T.A. Gogol and East // Astra Salvensis. - 2017. - Vol. 10. - Pp. 499-505

Nagumanova E. F. Khaybullina A. A., Khabibullina A. Z., Nagumanova E. F. Almenova A.B. Figurative In The Works Of Russian Classics And Tatar Poets Of The Early XX Century // Revista Publicando. - 2017. - Vol.4, Is.13. - pp. 763-772.

Baratova O. A., Shamina, V. B.; Apenko E. M. of Darkness" and Eugene O'Neill's Desire under the elms": on the problem of typological affinity. // Ad Alta Journal of Interdisciplinary Research. - 2017- V. 7, iss. 2. - Pp. 4042.
Breyeva T.N., Khabibullina L.F. National Myth in Russian and English Literature. - Kazan: RPC "Shkola", 2009. -612 p.

Ibragimov M.I. National Identity of Tatar Literature: Modern Research Methods: Essays. - Kazan: Publishing House of the ILLH named after G. Ibragimov, AS of the RT, 2018. - $104 \mathrm{p}$ 